Geochemical Journal, Vol. 3, pp. 187 to 200, 1970

\title{
A possible process for the fluctuation of halogen abundances in fumarolic gases
}

\author{
FUMIHIRO HONDA \\ Department of Earth Sciences, Nagoya University, \\ Chikusa, Nagoya, Japan.*
}

(Received December 26, 1969)

\begin{abstract}
Volcanic gases from Nasudake volcano were analyzed for chlorine, bromine and iodine. It was found that low temperature gases with high chlorine content had lower $\mathrm{Br} / \mathrm{Cl}$ and $\mathrm{I} / \mathrm{Cl}$ ratios than did high temperature gases.

To explain this finding, mixing processes of two kinds of gases are proposed. They are the original fumarolic gases of Nasudake volcano and the secondary fumarolic gases. The latter is assumed to be high in chlorine content and low in $\mathrm{Br} / \mathrm{Cl}$ and $\mathrm{I} / \mathrm{Cl}$ ratios. The experimental results on the distillation of a mixture of hydrochloric acid, hydrobromic acid and hydriodic acid solutions suggested that the hydrogen chloride in the secondary fumarolic gases may be supplied by distillation from the halogen compounds accumulated through the preceding fumarolic activity.
\end{abstract}

\section{INTRODUCTION}

In the previous paper (HoNDA et al., 1966), the authors discussed the abundances of chlorine and iodine in fumarolic gases from several active volcanoes in Japan, and found that: (1) The iodine to chlorine ratio of volcanic gases differs in different volcanoes, while in each volcano the gases show a rather constant value of iodine to chlorine ratio. (2) In low temperature fumarolic gases of Nasudake and Kirishima volcanoes, the iodine to chlorine ratio changes widely as the gas temperature falls.

In this paper, the author attempts to explain the change in iodine to chlorine and bromine to chlorine ratios with temperature for fumarolic gases of Nasudake volcano in terms of the alteration of fumarolic gases along their way to outlets.

\section{Experimental Procedure and Results}

Sampling of fumarolic gases Fumarolic gas samples were collected as condensate by the method described by Mizutani (1962a). Sampling site of fumarolic gases is shown in Fig.1. Some samples were collected in sodium hydroxide solution, and these sample

\footnotetext{
* Present address: The Research Institute of Iron, Steel and Other Metals, Tohoku University,
} Katahiracho, Sendai, Japan. 


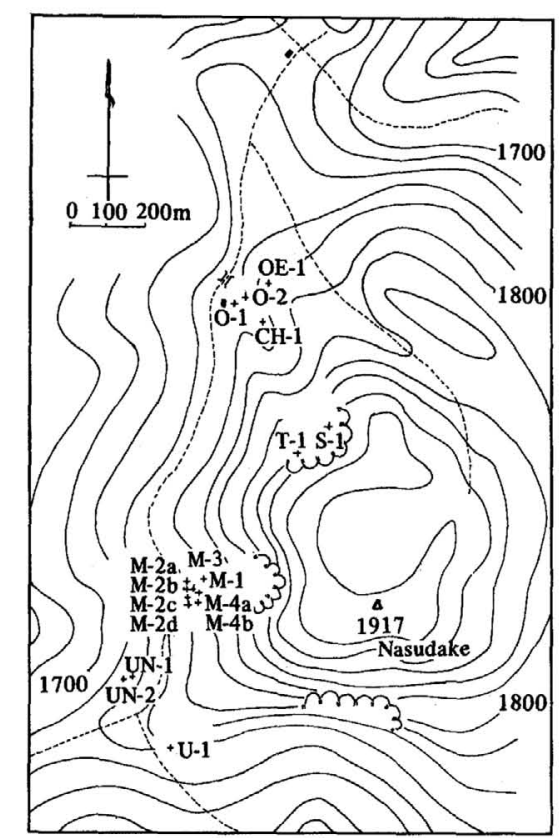

Fig.1. Sampling site of volcanic gases of Nasudake volcano.

solutions were treated with cation-exchanger ( $\mathrm{H}$-form) to remove sodium ions before the determination of halogens.

Analytical methods Analytical methods used for determination of the halogens and alkalies in fumarolic gases are:

Cl: Photometry with mercuric thiocyanate and iron alum (IwASAKI et al., 1952).

$\mathrm{Br}$ : Photometry with rosaniline after the separation by distillation with potassium permanganate and sulfuric acid (HUNTER and GolDSPINK, 1954).

I: Photometry after treating with sodium carbonate and hydrogen peroxide to oxidize sulfide to sulfate (UTSUMI et al., 1964).

$\mathrm{Na}, \mathrm{K}$ : Flamephotometry.

Results are listed in Tables 1 and 2. A part of results in these Tables have been reported in the previous report (HoNDA et al., 1966).

Distillation experiment with a mixture of hydrochloric, hydrobromic and hydriodic acids Three hundred $\mathrm{ml}$ of $6 \mathrm{~N}$ hydrochloric acid, $1 \mathrm{~g}$ of hydrobromic acid and $0.5 \mathrm{~g}$ of hydriodic acid were placed in a $500 \mathrm{ml}$ flask. A few $\mathrm{ml}$ of hypophosphorous acid was added into the flask to prevent oxidation of bromide and iodide into free bromine and iodine. Then the flask was placed in boilling water, and the released vapor was 
Table 1. Halogen contents of volcanic gases from Nasudake volcano

\begin{tabular}{|c|c|c|c|c|c|c|c|}
\hline Fumarole & $\begin{array}{l}\text { Temp. } \\
{ }^{\circ} \mathrm{C}\end{array}$ & $\begin{array}{c}\mathrm{pH} \\
\text { of condensed } \\
\text { water }\end{array}$ & $\begin{array}{c}\mathrm{Cl} \\
\mathrm{mg} / \mathrm{kgH}_{2} \mathrm{O}\end{array}$ & $\begin{array}{c}\mathrm{Br} \\
\mathrm{mg} / \mathrm{kgH}_{2} \mathrm{O}\end{array}$ & $\begin{array}{c}\mathrm{I} \\
\mathrm{mg} / \mathrm{kgH}_{2} \mathrm{O}\end{array}$ & $\frac{\mathrm{Br}}{\mathrm{Cl}} \times 10^{3}$ & $\frac{\mathrm{I}}{\mathrm{Cl}} \times 10^{4}$ \\
\hline M - $\quad 1,1960$ & 489 & 2.4 & 429 & 0.46 & 0.56 & 1.1 & 13 \\
\hline M - $\quad 1,1959$ & 480 & 2.1 & 600 & 0.73 & 0.71 & 1.2 & 12 \\
\hline$M-2 c, 1961$ & 410 & 2.2 & 510 & 0.44 & 0.48 & 0.86 & 9.4 \\
\hline M - $\quad 1,1963$ & 396 & 2.3 & 360 & 0.46 & 0.31 & 1.3 & 8.6 \\
\hline M - 1,1965 & 370 & 2.4 & 195 & 0.33 & 0.20 & 1.7 & 10 \\
\hline M - 2b,1960 & 352 & 1.0 & 480 & 0.54 & 0.57 & 1.1 & 12 \\
\hline M - 4a,1965 & 340 & 2.3 & 180 & 0.35 & 0.16 & 1.9 & 8.8 \\
\hline $\mathrm{CH} \cdot 1,1966$ & 308 & 2.5 & 170 & 0.10 & 0.072 & 0.59 & 4.2 \\
\hline M - 4a,1963 & 270 & - & 1210 & 0.58 & 0.37 & 0.48 & 3.1 \\
\hline M - 4b,1966 & 267 & 2.2 & 480 & 0.29 & 0.12 & 0.60 & 2.5 \\
\hline M - 4b,1965 & 261 & 1.9 & 470 & 0.50 & 0.23 & 1.1 & 4.9 \\
\hline $0-1 b, 1965$ & 228 & 2.1 & 710 & 0.67 & 0.63 & 0.95 & 8.9 \\
\hline o- 2b,1963 & 217 & - & 3660 & 0.92 & 0.91 & 0.25 & 2.5 \\
\hline$M-2 a, 1960$ & 195 & 1.0 & 9450 & 3.9 & 3.7 & 0.41 & 3.9 \\
\hline UN- 2,1966 & 190 & 2.0 & 570 & 0.13 & 0.043 & 0.23 & 0.75 \\
\hline $0-1 b, 1966$ & 188 & 1.9 & 560 & 0.56 & 0.24 & 1.0 & 4.3 \\
\hline O - 1a,1961 & 181 & 1.3 & 1370 & 3.6 & 1.3 & 2.6 & 9.5 \\
\hline O - 1d,1966 & 174 & 2.2 & 550 & 0.24 & 0.16 & 0.44 & 2.9 \\
\hline$O-2 a, 1965$ & 165 & 2.2 & 202 & 0.43 & 0.20 & 2.1 & 10 \\
\hline$O-2 c, 1963$ & 160 & - & 8130 & 0.90 & 0.92 & 0.11 & 1.1 \\
\hline UN- 1,1965 & 158 & 1.4 & 4280 & 1.4 & 1.5 & 0.33 & 3.5 \\
\hline $\mathrm{U}-1,1966$ & 148 & 1.7 & 1240 & 0.63 & 0.34 & 0.51 & 2.7 \\
\hline UN- 1,1963 & 138 & - & 9690 & 2.2 & 1.7 & 0.23 & 1.8 \\
\hline U - $\quad 1,1961$ & 132 & 1.4 & 1810 & 0.20 & 0.49 & 0.11 & 2.7 \\
\hline$U-\quad 1,1963$ & 130 & $\cdot$ & 1830 & 0.78 & 0.91 & 0.43 & 5.0 \\
\hline S - $\quad 1,1962$ & 129 & - & 570 & 0.27 & 0.36 & 0.47 & 6.3 \\
\hline $0-2 b, 1965$ & 125 & 2.3 & 210 & 0.29 & 0.16 & 1.4 & 7.6 \\
\hline $\mathrm{T} \cdot \quad \mathbf{1 , 1 9 6 3}$ & 120 & - & 860 & 0.43 & 0.44 & 0.50 & 5.1 \\
\hline $0-1,1959$ & 119 & 1.2 & 3160 & 4.5 & 3.9 & 1.4 & 12 \\
\hline OE- $\quad 1,1965$ & 119 & 2.1 & 410 & 0.51 & 0.40 & 1.1 & 9.8 \\
\hline T - $\quad 1,1962$ & 119 & - & 380 & 0.31 & 0.38 & 0.82 & 10 \\
\hline o- 2b,1966 & 118 & 2.6 & 120 & 0.13 & 0.038 & 1.1 & 3.1 \\
\hline O- $\quad 4,1963$ & 117 & - & 1330 & 1.3 & 1.2 & 1.0 & 9.0 \\
\hline$M-\quad 3,1960$ & 97 & 0.9 & 8700 & 0.80 & 0.67 & 0.092 & 0.77 \\
\hline
\end{tabular}


Table 2. Sodium and potassium contents of volcanic gases from Nasudake volcano

\begin{tabular}{lcccc}
\hline \hline Fumarole & $\begin{array}{c}\text { Temp. } \\
{ }^{\circ} \mathrm{C}\end{array}$ & $\begin{array}{c}\mathrm{Cl} \\
\mathrm{mg} / \mathrm{kgH}_{2} \mathrm{O}\end{array}$ & $\begin{array}{c}\mathrm{Na} \\
\mathrm{mg} / \mathrm{kgH}_{2} \mathrm{O}\end{array}$ & $\begin{array}{c}\mathrm{K} \\
\mathrm{mg} / \mathrm{kgH}_{2} \mathrm{O}\end{array}$ \\
\hline $\mathrm{M}-1,1960$ & 489 & 429 & 1.1 & 0.5 \\
$\mathrm{M}-1,1959$ & 480 & 600 & 0.8 & 0.5 \\
$\mathrm{M}-1,1963$ & 396 & 360 & 0.2 & 0.2 \\
$\mathrm{M}-2 \mathrm{~b}, 1960$ & 352 & 480 & 0.5 & 0.2 \\
O- 2b,1963 & 217 & 3660 & 0.8 & 0.3 \\
$\mathrm{M}-2 \mathrm{a}, 1960$ & 195 & 9450 & 1.3 & 0.5 \\
O - 2c,1963 & 160 & 8130 & 0.8 & 0.3 \\
$\mathrm{UN}-1,1963$ & 138 & 9690 & 1.1 & 0.5 \\
$\mathrm{U}-1,1961$ & 132 & 1810 & 3.2 & 0.6 \\
$\mathrm{OE}-1,1965$ & 119 & 410 & 0.4 & 0.2 \\
$\mathrm{O}-1,1959$ & 119 & 3160 & 0.6 & 0.3 \\
$\mathrm{O}-2 \mathrm{~b}, 1966$ & 118 & 120 & 0.4 & 0.2 \\
$\mathrm{M}-3,1960$ & 97 & 8700 & 1.0 & 0.3 \\
\hline
\end{tabular}

Table 3. Result of experimental distillation of $\mathrm{HCl}-\mathrm{HBr}-\mathrm{HI}$ mixture (1000: $14: 7$ )

\begin{tabular}{lcc|ccccc}
\hline \multicolumn{3}{c|}{ In distilling device } & \multicolumn{5}{c}{ In distillate } \\
\hline Vol. of $\mathrm{HCl}$ & $\mathrm{Br}(\mathrm{A})$ & $\mathrm{I}(\mathrm{B})$ & $\mathrm{Cl}$ & $\mathrm{Br}(\mathrm{C})$ & $\mathrm{I}(\mathrm{D})$ & $(\mathrm{C}) /(\mathrm{A})$ & $(\mathrm{D}) /(\mathrm{B})$ \\
$\mathrm{ml}$ & $\mathrm{mg} / \mathrm{ml}$ & $\mathrm{mg} / \mathrm{ml}$ & $\mathrm{mg} / \mathrm{ml}$ & $\mu \mathrm{g} / \mathrm{ml}$ & $\mu \mathrm{g} / \mathrm{ml}$ & $\mathrm{X} 10^{3}$ & $\mathrm{X} 10^{3}$ \\
300 init. & 3.33 & 1.69 & & & & & \\
280 & 3.57 & 1.78 & 162 & tr. & 0.0 & 0 & 0 \\
260 & 3.84 & 1.92 & 176 & tr. & 0.5 & 0 & 0.2 \\
240 & 4.16 & 2.08 & 191 & tr. & 0.5 & 0 & 0.2 \\
220 & 4.54 & 2.27 & 206 & tr. & 0.5 & 0 & 0.2 \\
200 & 5.00 & 2.50 & 215 & 2.3 & 3.8 & 0.46 & 1.5 \\
180 & 5.55 & 2.77 & 215 & 3.3 & 4.3 & 0.59 & 1.5 \\
160 & 6.26 & 3.12 & 218 & 3.2 & 4.3 & 0.51 & 1.4 \\
140 & 7.14 & 3.57 & 215 & 3.0 & 4.7 & 0.42 & 1.3 \\
120 & 8.32 & 4.16 & 216 & 3.0 & 4.8 & 0.36 & 1.2 \\
100 & 10.0 & 5.00 & 216 & 3.4 & 5.0 & 0.34 & 1.0 \\
80 & 12.5 & 6.25 & 215 & 3.9 & 5.0 & 0.31 & 0.8 \\
60 & 16.6 & 8.33 & 215 & 6.1 & 5.9 & 0.37 & 0.7 \\
40 & 25.0 & 12.5 & 215 & 12.5 & 14.9 & 0.50 & 1.2 \\
20 & 50.0 & 25.0 & 216 & 25.4 & 32.5 & 0.50 & 1.3 \\
11 resid. & 90.8 & 45.4 & 216 & 78.1 & 86.1 & 0.86 & 1.9 \\
\hline
\end{tabular}


introduced into a condenser by a stream of argon. Every $20 \mathrm{ml}$ of distillate was successively analyzed for chlorine, bromine and iodine. The results obtained are shown in Table 3.

\section{DisCUSSION}

Table 1 shows that some samples of rather low temperature (below $300^{\circ} \mathrm{C}$ ) contain relatively large amounts of chlorine (above $1,000 \mathrm{mgCl} / \mathrm{kgH}_{2} \mathrm{O}$ ), as compared with other samples of this volcano. It is also found from the gas temperature and $\mathrm{Br} / \mathrm{Cl}$ and $\mathrm{I} / \mathrm{Cl}$ ratios given in Table 1 that volcanic gases examined may be divided into the following two groups: (1) Gases with temperatures above $300{ }^{\circ} \mathrm{C}$, which have rather constant values of $\mathrm{Br} / \mathrm{Cl}$ ratio, $(1-2) \times 10^{-3}$, and $\mathrm{I} / \mathrm{Cl}$ ratio, $(10-13) \times 10^{-4}$ The gases of this group were collected from a main fumarole of Nasudake, $M-1$, and some other fumaroles of high activity. (2) Gases with temperatures below $300^{\circ} \mathrm{C}$, which have widely scattered values of $\mathrm{Br} / \mathrm{Cl}$ ratio, $(0.1-2) \times 10^{-3}$, and $\mathrm{I} / \mathrm{Cl}$ ratio, $(0.7-13) \times 10^{-4}$. The group of lower temperature contains gases with high chlorine content and low $\mathrm{Br} / \mathrm{Cl}$ and $\mathrm{I} / \mathrm{Cl}$ ratios. Therefore, their lower $\mathrm{Br} / \mathrm{Cl}$ and $\mathrm{I} / \mathrm{Cl}$ ratios are possibly related to their unusually high chlorine content. These low temperature volcanic gas samples show similarity or commonness in their mode of occurrence and in chemical composition: (1) These gases effuse from fumaroles of low activity, which are located close to the outlets of main fumaroles with higher temperatures. (2) They often change their chemical composition, especially halogen contents. (3) The effusion site shifts from time to time. These features offer an important clue to the possible mechanism of producing such lower temperature gases.

Assuming that the original fumarolic gases of this volcano have the $\mathrm{Br} / \mathrm{Cl}$ and $\mathrm{I} / \mathrm{Cl}$ ratios of $1.5 \times 10^{-3}$ and $13 \times 10^{-4}$, respectively, the amount of "excess chlorine" is defined as follows:

Excess $\mathrm{Cl}=\mathrm{Cl}$ observed $-\mathrm{Br} /\left(1.5 \times 10^{-3}\right)$

Excess $\mathrm{Cl}=\mathrm{Cl}$ observed - I / $\left(13 \times 10^{-4}\right)$.

The results obtained are given in Table 4. The agreement between the values from equations (1) and (2) is satisfactory for each sample. When the values of "excess chlorine" thus defined are plotted against the total chlorine contents observed, as given in Figs. 2 and 3, it is seen that the amount of "excess chlorine" increases proportionally to the increase in the total chlorine content. This result encourages the author to consider the existence of secondarv fumarolic gases with high chlorine content and low $\mathrm{Br} / \mathrm{Cl}$ and $\mathrm{I} / \mathrm{Cl}$ ratios.

When the observed $\mathrm{Br} / \mathrm{Cl}$ and $\mathrm{I} / \mathrm{Cl}$ ratios are plotted against the gas temperature (Figs. 4 and 5), it is found that the low temperature gases may be also divided into the following two groups with a few exceptions: (1) The gases having $\mathrm{Br} / \mathrm{Cl}$ and $\mathrm{I} / \mathrm{Cl}$ ratios similar to those in the high temperature gases, which have rather low "excess chlorine" contents. (2) The gases having lower $\mathrm{Br} / \mathrm{Cl}$ and $\mathrm{I} / \mathrm{Cl}$ ratios than the high temperature 
Table 4. Excess chlorine in volcanic gases

\begin{tabular}{|c|c|c|c|}
\hline Fumarole & $\underset{{ }^{\circ} \mathrm{C}}{\text { Temp. }}$ & $\begin{array}{l}\text { Excess Cl from } \\
\text { eq.(1) ppm }\end{array}$ & $\begin{array}{l}\text { Excess Cl from } \\
\text { eq.(2) } \mathrm{ppm}\end{array}$ \\
\hline$M-1,1960$ & 489 & 130 & 0 \\
\hline$M-1,1959$ & 480 & 120 & 50 \\
\hline$M-2 c, 1961$ & 410 & 220 & 140 \\
\hline$M-1,1963$ & 396 & 60 & 120 \\
\hline$M-1,1965$ & 370 & -20 & 40 \\
\hline$M-2 b, 1960$ & 352 & 120 & 40 \\
\hline$M-4 a, 1965$ & 340 & -50 & 60 \\
\hline $\mathrm{CH}-\quad 1,1966$ & 308 & 100 & 110 \\
\hline$M-4 a, 1963$ & 270 & 830 & 930 \\
\hline$M-4 b, 1966$ & 267 & 290 & 390 \\
\hline$M-4 b, 1965$ & 261 & 140 & 290 \\
\hline $0-1 b, 1965$ & 228 & 270 & 220 \\
\hline$O-2 b, 1963$ & 217 & 3060 & 2960 \\
\hline$M-2 a, 1960$ & 195 & 6900 & 6600 \\
\hline UN- 2,1966 & 190 & 490 & 540 \\
\hline$O-1 b, 1966$ & 188 & 190 & 370 \\
\hline$O-1 a, 1961$ & 181 & -1140 & 370 \\
\hline$O-1 d, 1966$ & 174 & 390 & 430 \\
\hline$O-2 a, 1965$ & 165 & -80 & 50 \\
\hline o - 2c,1963 & 160 & 7540 & 7240 \\
\hline UN- $\quad 1,1965$ & 158 & 3080 & 3100 \\
\hline$U-1,1966$ & 148 & 830 & 980 \\
\hline UN- $\quad 1,1963$ & 138 & 8240 & 8390 \\
\hline$U-1,1961$ & 132 & 1680 & 1400 \\
\hline$U-1,1963$ & 130 & 1320 & 1100 \\
\hline$S-1,1962$ & 129 & 400 & 290 \\
\hline$O-2 b, 1965$ & 125 & 20 & 90 \\
\hline$T-1,1963$ & 120 & 580 & 520 \\
\hline $0-1,1959$ & 119 & 200 & 160 \\
\hline OE- $\quad 1,1965$ & 119 & 80 & 100 \\
\hline$T-1,1962$ & 119 & 180 & 90 \\
\hline$o-2 b, 1966$ & 118 & 40 & 90 \\
\hline$O-4,1963$ & 117 & 480 & 410 \\
\hline$M-3,1960$ & 97 & 8200 & 8200 \\
\hline
\end{tabular}




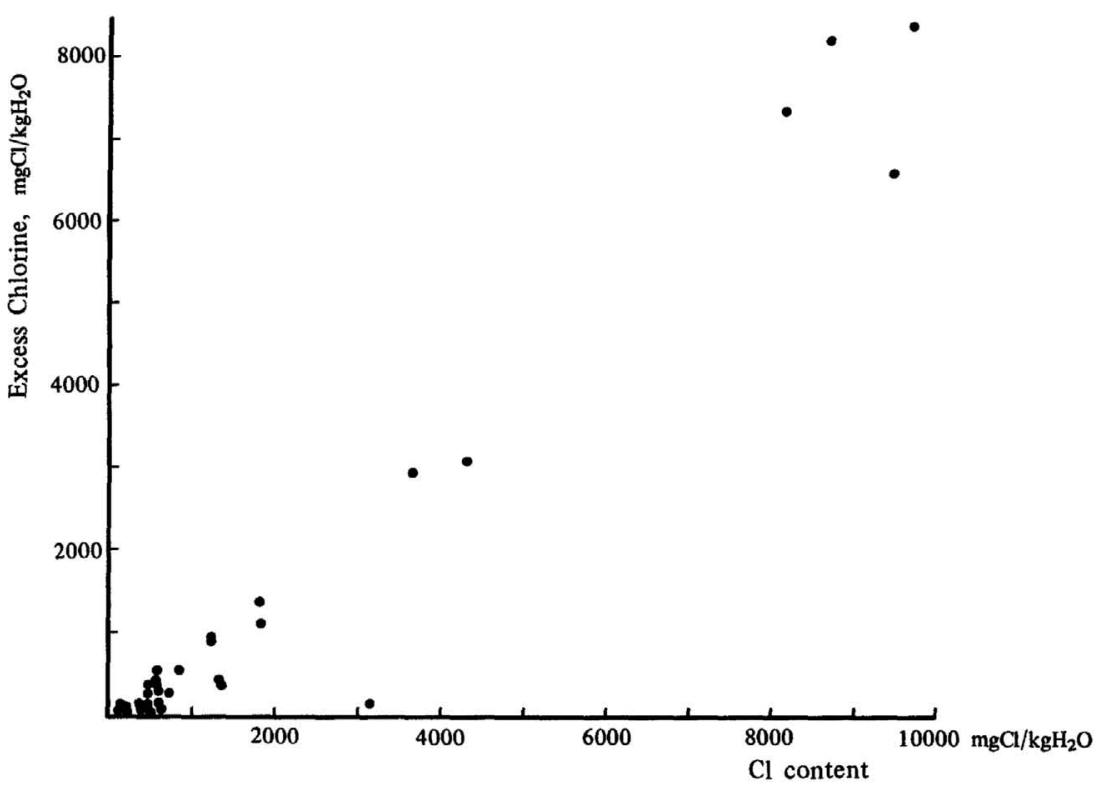

Fig.2. Relationship between chlorine content and "excess chlorine" calculated from equation (1).

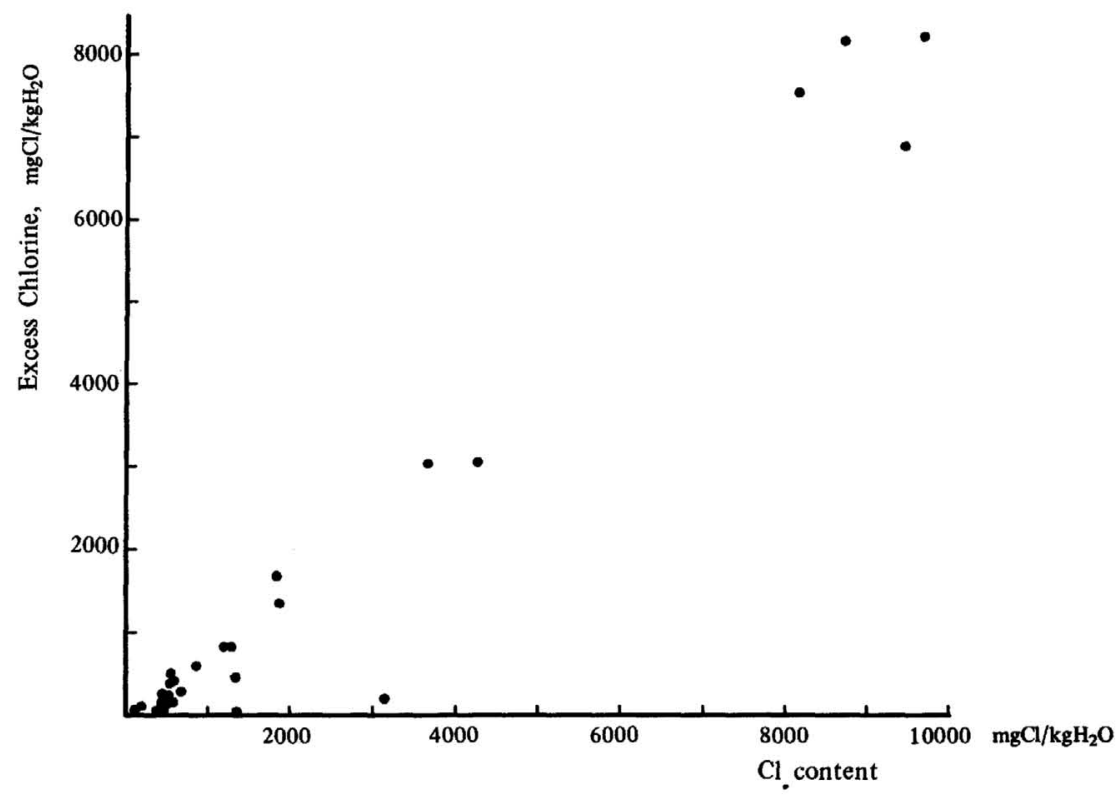

Fig.3. Relationship between chlorine content and "excess chlorine" calculated from equation (2). 


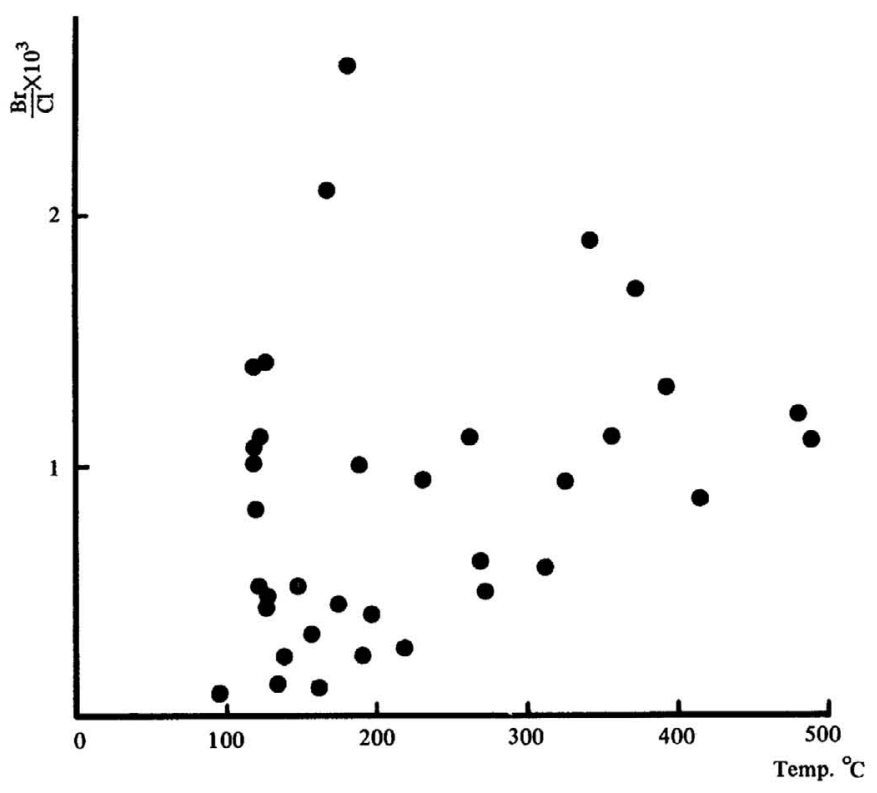

Fig.4. Relationship between bromine to chlorine ratio and the gas temperature.

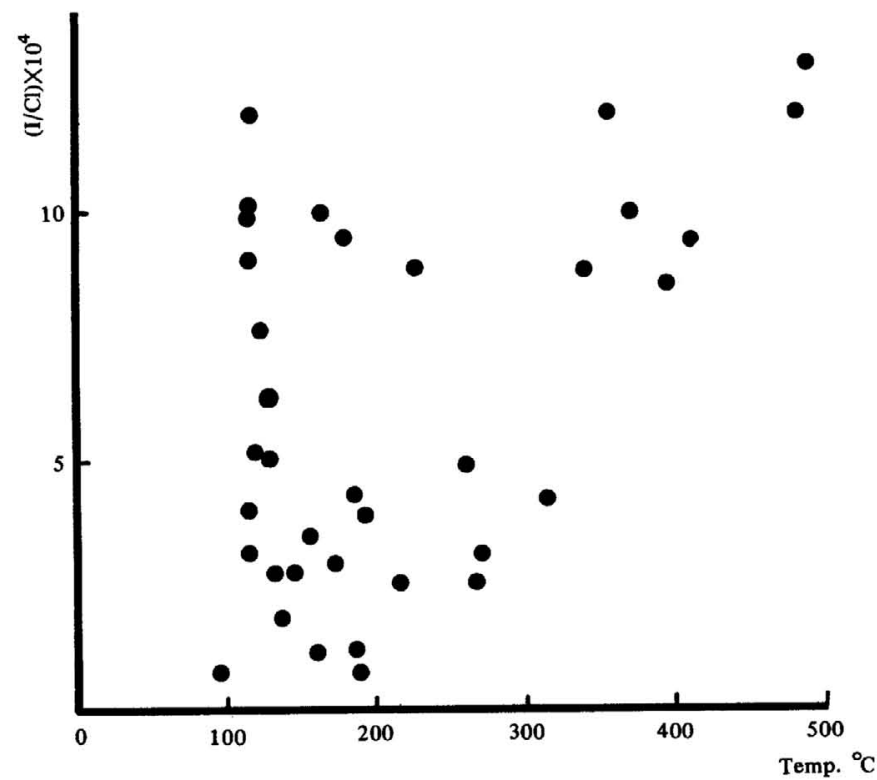

Fig.5. Relationship between iodine to chlorine ratio and the gas temperature. 
gases, and high "excess chlorine" content.

The gases of the group (1) may be regarded as a product of simple cooling of the high temperature gases. For the gases of the group (2), mixing of two kinds of gases may be proposed. A mixing model of two kinds of fumarolic gases was proposed previously by MizUTANI (1962b) to explain the occurrence of lower temperature gases of Showashinzan volcano. Suzuoki (1965), and Honda and OANA (1968) also applied a similar idea to the studies of the variations in the concentrations of chemical components in fumarolic gases from Nasudake volcano.

One is the original fumarolic gases, which may be represented by the high temperature gases at temperatures above $300^{\circ} \mathrm{C}$, and the other is the secondary fumarolic gases. Assuming that the secondary gases have $\mathrm{Br} / \mathrm{Cl}$ and $\mathrm{I} / \mathrm{Cl}$ ratios of $0.1 \times 10^{-3}$ and $0.7 \times 10^{-4}$, respectively, the chlorine content of the secondary gases may be estimated to be larger than $10 \mathrm{gCl} / \mathrm{kgH}_{2} \mathrm{O}$ and the gas temperature about $100^{\circ} \mathrm{C}$.

Possible processes for the formation of secondary fumarolic gases The following possible sources of "excess chlorine" may be considered: (1) Halide minerals formed on wall rocks by sublimation or reactions between volatile halide compounds in gas phase and wall rock minerals. (2) Absorbed or occluded halogens in the wall rocks vitrified through fumarolic alteration. (3) Halogen acid solutions accumulated underground around fumaroles. They are discussed respectively.

(1) As the condensed water samples contain only traces of metallic components (Table 2), the direct contribution of metallic halide vapor to the chlorine in fumarolic gases may be ignored. Strong acidity of condensed water samples suggests that the chlorine existed as hydrogen chloride in fumarolic gases. If metal halide deposits can supply halogens to fumarolic gases, reactions between metal halide and water vapor must be considered. For example, Sugiura (1968) emphasized the role of water vapor in extracting halogens from halide minerals and igneous rocks on heating. HoNDA (1970) discussed the possibility of water vapor-halides reactions in fumarolic conditions, and suggested that fumarolic gases are saturated with hydrogen chloride with respect to alkali chlorides but not with hydrogen iodide with respect to alkali iodides. This implies that reactions between fumarolic gases and alkali chloride to form hydrogen chloride hardly proceed in fumarolic gases.

(2) The fumarolic and geothermal alteration of silicate rocks have been studied by many researchers. NoBLE et al., (1967) analyzed crystallized and glassy rocks for chlorine and fluorine, and concluded that glassy rocks are apt to lose or gain these elements through prolonged contact with ground water. LovERING (1957) extensively investigated altered rocks at Valley of Ten Thousand Smokes, Alaska, and found that chlorine and fluorine are highly concentrated in altered rocks located close to gas orifices. A similar concentration of chlorine and fluorine on silicate rocks in fumaroles was observed at Satsuma Iwojima volcano, Japan by YoshidA et al. (1969). The present 
Table 5. Chlorine and fluorine contents of the gas altered rocks collected at fumarolic area of Nasudake

\begin{tabular}{ccrrl}
\hline \hline Sampling site & $\begin{array}{c}\text { Temp. } \\
{ }^{\circ} \mathrm{C}\end{array}$ & $\begin{array}{c}\mathrm{Cl} \\
\mathrm{mg} / \mathrm{kg}\end{array}$ & $\begin{array}{c}\mathrm{F} \\
\mathrm{mg} / \mathrm{kg}\end{array}$ & \multicolumn{1}{c}{ Remarks } \\
\hline O - 1 & 200 & 2850 & 8540 & Dark grey mud \\
UN- 2 & 190 & 6690 & 4830 & Wall rock \\
O - 2 & 118 & 2080 & 7480 & Mud on a gas vent \\
M -4b & 267 & 110 & 220 & Porous altered rock \\
CH- 1 & - & 1950 & 3390 & Wall rock of an extinct fumarole \\
M - 1 & 100 & 3360 & 2890 & Dark altered rock \\
O - 2 & 90 & 1630 & 4090 & Upper part of mud on a gas vent \\
M - 4a & 310 & 110 & 330 & Grey altered rock \\
O - 1b & 108 & 270 & 3840 & Wall rock \\
O - 1b & 170 & 1090 & 5360 & Dark grey mud \\
M -4b & 105 & 4120 & 1050 & Wall rock \\
\hline
\end{tabular}

author also examined altered rocks collected from the fumarolic area of Nasudake volcano for chlorine and fluorine, and found that the altered rock samples contained large amounts of chlorine and fluorine, as shown in Table 5, while only one to a few tenth percent of the chlorine and fluorine in the samples could be leached with water. The altered rock samples examined were collected from the wall of active fumaroles, where temperatures of about $100^{\circ} \mathrm{C}$ to $300^{\circ} \mathrm{C}$ were recorded. Microscopic tests revealed that these samples were completely vitrified by fumarolic alterations. Therefore, most of chlorine and fluorine in altered rocks seems to be occluded in the vitrified part. These results corroborate the possibility that the vitrified part of altered wall rocks is a source for halogens in secondary fumarolic gases. According to SugIURA (1968), the chlorine in volcanic rocks and glasses can be readily released as hydrogen chloride by water vapor distillation at temperatures above $300^{\circ} \mathrm{C}$. If the chlorine occluded in the vitrified wall rocks is also easily released by water vapor distilla. on, the released hydrogen chloride may be regarded as a secondary chloride. For example,

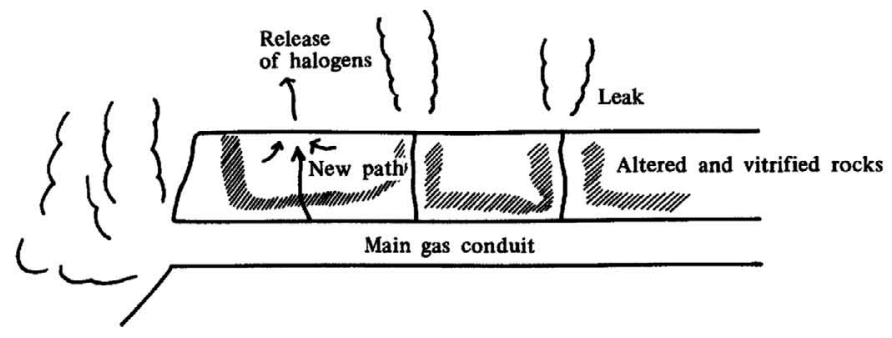

Fig.6. A model of releasing halogens from vitrified altered rocks which occluded large amounts of halogens. 
when high temperature fumarolic water vapor comes into contact with vitrified part of wall rocks by a change of the path for leaking gases from the main conduit of fumarolic gases, as shown in Fig.6, the halogens in the wall rocks may be supplied as hydrogen chloride to the gases. This process may be responsible for the formation of gases with high chlorine content. The extent of the contribution of this process to the formation of secondary gases, however, requires further detailed studies on the chlorine, bromine and iodine in the vitrified wall rocks of fumaroles.

(3) UENo (1965) made a water vapor distillation experiment on hydrochloric acid solution with a small amount of hydrobromic acid, and obtained some interesting results on bromine to chlorine ratio in the distillate. In his experiment, azeotropic solution of hydrochloric acid with hydrobromic acid (initial mixing ratio: $\mathrm{Br} / \mathrm{Cl}=10^{-3}$ in weight) released vapor with low bromine to chlorine ratio $\left(\mathrm{Br} / \mathrm{Cl}=10^{-6}\right)$. In an attempt to develope this experiment, the present author also made a distillation experiment using a mixture of hydrogen chloride, hydrogen bromide and hydrogen iodide. The results are listed in Table 3. This Table shows that iodide is remarkably concentrated in liquid phase just as bromide during its distillation process. This implies that iodine and bromine contents of distillate are considerably lower than those of the initial solution. This distillation process seems to be suitable for explaining the origin of "excess chlorine" in fumarolic gases. Fig. 7 shows a possible model for the formation

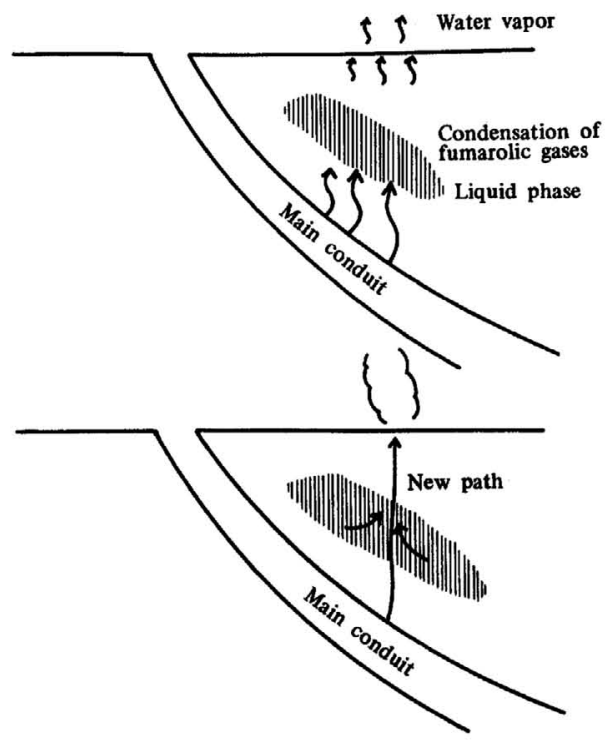

Fig.7. A possible model for the formation of the gases containing "excess chlorine" by water vapor distillation process. 
of the gases containing "excess chlorine" by water vapor distillation process. In an earlier stage of fumarolic activity, fumarolic gases form a liquid phase by condensation of water vapor. $\mathrm{HCl}, \mathrm{HBr}, \mathrm{HI}$ and others are dissolved in it. Then high temperature fumarolic gases come into the liquid phase through a new path and the hydrochloric acid in the liquid phase is added to the gas phase by vapor distillation. At later stage of this distillation process, the gases having higher values of $\mathrm{Br} / \mathrm{Cl}$ and $\mathrm{I} / \mathrm{Cl}$ ratios may be released. The period of releasing gases with higher $\mathrm{Br} / \mathrm{Cl}$ and $\mathrm{I} / \mathrm{Cl}$ ratios, however, is very short as compared with the period of releasing gases with lower $\mathrm{Br} / \mathrm{Cl}$ and $\mathrm{I} / \mathrm{Cl}$ ratios. This is a reason why the opportunity of finding gases of high $\mathrm{Br} / \mathrm{Cl}$ and $\mathrm{I} / \mathrm{Cl}$ ratios is scanty.

YosHidA et al. (1966) found that bromine and iodine were highly concentrated in the concentrated hydrochloric acid solution occluded in a loose mass of some siliceous volcanic sublimates collected at Satsuma Iwojima volcano, Kyusyu, Japan. This concentrated solution of hydrogen chloride may be regarded as a residual fraction of condensed water from fumarolic gases. On the other hand, Honda and MizuTANI (1967) also found concentrated hydrochloric acid solutions in siliceous sublimates collected at Kuju Iwoyama volcano. These solutions, however, showed very low $\mathrm{Br} / \mathrm{Cl}$ and $\mathrm{I} / \mathrm{Cl}$ ratios. In the fumarolic area of Showashinzan volcano, low temperature fumarolic gases having an unusually high hydrogen chloride content were collected by

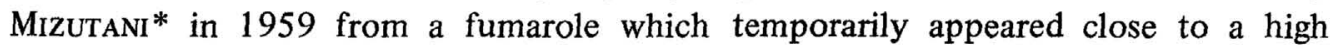
temperature gas vent after a heavy rain fall. This implies that the halogen compounds may be accumulated in the wall rocks of fumarole and rejoined to fumarolic gases as hydrogen chloride by means of rain water.

\section{ConClusion}

Among low temperature fumarolic gases collected from Nasudake volcano, some showed high chlorine contents and low $\mathrm{Br} / \mathrm{Cl}$ and $\mathrm{I} / \mathrm{Cl}$ ratios. For the process of formation of these gases, mixing of secondary gases with the primary fumarolic gases is proposed.

The secondary gases proposed have a hydrogen chloride content above 10 $\mathrm{gCl} / \mathrm{kgH}_{2} \mathrm{O}, \mathrm{Br} / \mathrm{Cl}$ ratio below $0.1 \times 10^{-3}, \mathrm{I} / \mathrm{Cl}$ ratio below $0.7 \times 10^{-4}$, and a temperature of $100^{\circ} \mathrm{C}$. The hydrogen halides in these secondary gases are supplied probably by vapor distillation from hydrochloric acid solution formed around fumaroles and/or from halide compounds in altered wall rocks.

\section{ACKNOWLEDGEMENTS}

The author wishes to express his sincere gratitude to Professor SHINYA OANA of Nagoya

* Personal communication. 
University, who gave him instructive guidance and encouragement throughout this work. He is greatly indebted to Dr. NOBUYUKI NAKAI of Nagoya University who gave generously of his useful suggestion.

Especial thanks are due to Dr. YoSHIHIKo MIZUTANI of Nagoya University who gave him constant and valuable advice, and critically read this manuscript. Many samples of volcanic gases were kindly offered by him.

\section{REFERENCES}

HONDA, F. (1970) Geochemical study of iodine in volcanic gases. II. Behavior of iodine in volcanic gases. Geochem. J. 3, 201-211.

Honda, F., Mizutani, Y., Sugiura, T. and OANa, S. (1966) A geochemical study of iodine in volcanic gases. Bull. Chem. Soc. Japan 39, 2690-2695.

HONDA, F. and MiZuTANI, Y. (1967) Silicon content of fumarolic gases and the formation of siliceous sublimate. Geochem. J. 2, 1-9.

HONDA, F. and OANA, S. (1968) Sulfur isotopes at Nasudake and Tamagawa volcanoes. Read at the 1968 Symposium of Geochemical Society of Japan.

HUNTER, G. and GOLDSPINK, A. (1954) The micro-determination of bromide in presence of chloride. Analyst 79, 467-475.

IWASAKI, I., UTSUMI, S. and OZAWA, T. (1952) New colorimetric determination of chloride using mercuric thiocyanate and ferric ion. Bull. Chem. Soc. Japan 25, 226.

LOVERING, T. S. (1957) Halogen acid alteration of ash at fumarole No.1, Valley of Ten Thousand Smokes, Alaska. Bull. Geol. Soc. Am. 68, 1585-1604.

MiZUTANI, Y. (1962a) Chemical analyses of volcanic gases. J. Earth Sci. Nagoya Univ. 10, $125-134$.

MiZUTANI, Y. (1962b) Origin of lower temperature fumarolic gases of Showashinzan. ibid. 10, $135-148$.

NoBle, D. C., SMITH, V. C. and PECK, L. C. (1967) Loss of halogens from crystallized and glassy silicic volcanic rocks. Geochim. Cosmochim. Acta 31, 215-223.

SUGIURA, T. (1968) An experimental study on the role of water vapor in the distillation of fluorine and chlorine in volcanic rocks. Bull. Chem. Soc. Japan 41, 1588-1600.

SUZUOKI, T. (1965) A geochemical study of selenium in volcanic exhalation and sulfur deposits. II. On the behavior of selenium and sulfur in volcanic exhalation and sulfur deposits. ibid. 38, 1940-1946.

UENO, S. (1965) Determination of trace amount of hydrobromic acid in the hydrochloric acid. Japan Analyst 14, 219-223 (in Japanese).

Utsumi, S., Shiota, M., Yonehara, N. and IWASAKI, I. (1964) Photometric determination of minute amount of iodine by the catalytic reaction. J. Chem. Soc. Japan, Pure Chem. Sect. 85, 32-35 (in Japanese).

YoshidA, M. and group to study Satsuma-Iwo-Jima Volcano. Read at the Symposium of Geochemical Society of Japan, 1966.

YoshidA, M., OzAWA, T. and OSSAKA, J. (1966) A singular silica sublimate mineral found in Satuma-Iwo-Zima volcano (I). J. Japan. Assoc. Miner. Petro. Econ. Geol. 55, 201-211 (in Japanese). 
Yoshida, M., OZAWA, T. and OSSAKA, J. (1969) Fluorine and chlorine contents of the rockalteration products by volcanic gases obtained at Satuma-Iwo-Zima. Bull. Chem. Soc. Japan 90, 159-162. 